\title{
A Humboldtian approach to life and climate of the geological past : Estimating palaeotemperature from dental traits of mammalian communities
}

\section{Oksanen, Otto}

2019-08

Oksanen , O , Zliobaite , I, Saarinen , J , Lawing , A M \& Fortelius , M 2019 , ' A Humboldtian approach to life and climate of the geological past : Estimating palaeotemperature from dental traits of mammalian communities ' , Journal of Biogeography , vol. 46 , no. 8 , pp. 1760-1776 . https://doi.org/10.1111/jbi.13586

http://hdl.handle.net/10138/322032

https://doi.org/10.1111/jbi.13586

acceptedVersion

Downloaded from Helda, University of Helsinki institutional repository.

This is an electronic reprint of the original article.

This reprint may differ from the original in pagination and typographic detail.

Please cite the original version. 


\title{
A Humboldtian approach to life and climate of the geological past: estimating palaeotemperature from dental traits of mammalian communities
}

\author{
Otto Oksanen ${ }^{1,2}$, Indrè Žliobaitè ${ }^{2,3}$, Juha Saarinen ${ }^{1}$, A. Michelle Lawing ${ }^{4}$, Mikael Fortelius ${ }^{1,3,5}$ \\ 1 Department of Geosciences and Geography, University of Helsinki, Finland \\ 2 Department of Computer Science, University of Helsinki, Finland \\ 3 Finnish Museum of Natural History, Finland \\ 4 Ecosystem Science and Management, Texas A\&M University, USA \\ 5 Museum of Natural History, Berlin, Germany
}

Correspondence: otto.oksanen@helsinki.fi

March 27, 2019

\section{Acknowledgements}

We thank Soledad Domingo and Juan Manuel Jiménez Arenas for updating some of the faunal lists for the fossil data. We thank Hui Tang for mapping Bioclim2 and elevation data to grid-cells, published in Žliobaitè et al. (2018). We thank Elina Hernesniemi for photos of teeth. Joshua Samuels, Jenny McGuire, and an anonymous reviewer provided insightful comments and suggestions that helped to improve the quality of the manuscript. MF was the recipient of a research award from the Alexander von Humboldt Foundation. Research leading to these results was partially funded by the Academy of Finland (grant no. 314803 to IŽ and grant no. 274779 to MF). This work was also supported by the USDA NIFA Hatch TEX09600 project 1003462 and the Integrative Climate Change Biology group (a scientific program of the International Union of Biological Sciences). This is a contribution from the Valio Armas Korvenkontio Unit of Dental Anatomy in Relation to Evolutionary Theory.

\section{Abstract}

Aim The links between geo- and biodiversity, postulated by Humboldt, can now be made quantitative. Species are adapted to their environments and interact with their environments by having pertinent functional traits. We aim to improve global ecometric models using functional traits for estimating palaeoclimate and apply models to Pleistocene fauna for palaeoclimate interpretation. Location Global at present day, Pleistocene of Europe for fossil data analysis.

Taxa Artiodactyla, Perissodactyla, Proboscidea and Primates.

Methods We quantify functional traits of large mammal communities and develop statistical models linking trait distributions to local climate at present day. We apply these models to the fossil record, survey functional traits, and quantitatively estimate climates of the past. This approach to analyzing functional relationships between faunal communities and their environments is called ecometrics. Results and main conclusions Here we present new global ecometric models for estimating mean annual and minimum temperature from dental traits of present day mammalian communities. We also present refined models for predicting net primary productivity. Using dental ecometric models, we produce palaeoclimate estimates for 50 Pleistocene fossil localities in Europe and show that the estimates are consistent with trends derived from other proxies, especially for minimum temperatures, which we hypothesise to be ecologically limiting. Our new temperature models allow us to trace the distribution of freezing and non-freezing ecosystems in the recent past, opening new perspectives on the evolution of cold-adaptive biota as the Pleistocene cooling progressed. 
Keywords: ecometrics, palaeoclimate, palaeotemperature, dental traits, plant-eating mammals, predictive modelling, Alexander von Humboldt

\section{INTRODUCTION}

The notion that the biosphere has a long history that has unrolled under the influence of physical changes affecting Earth's surface modulated by the interactions between organisms and populations is so self-evident to a modern scientist that we rarely stop to consider its origin, apart from an occasional, reverent acknowledgement of "ever since Darwin". Yet Darwin himself lived and breathed the prehistory of what would later become known as "Darwinism". Much of this prehistory came to flower in the core works of Alexander von Humboldt. Indeed, so anxious was Darwin to have Humboldt's 7-volume Personal Narrative of Travels to the Equinoctial Regions of the New Continent constantly at hand during his famous voyage on HMS Beagle that he asked the captain before the departure for permission to bring it to his small cabin (Wulf, 2015, footnote p. 218). That this book became a key source and inspiration to him, rivalled only by Lyell's Principles of Geology, is abundantly clear from his many enthusiastic references to it in his notes, letters and publications (Wulf, 2015, p. 232).

Although Alexander von Humboldt never reached Darwin's concrete, process-level understanding of evolutionary change, the more abstract idea of life's transformation in harmony with changing environmental circumstances is strongly evident in much of his writing, including the Personal Narrative, Views of Nature, and Cosmos. Humboldt, it has been said, was a "pre-Darwinian Darwinist" (Wulf, 2015, p. 243) and his view of the world is a direct precursor of the view expressed in Darwin's famous passage on "the tangled bank" in the last paragraph of the Origin: "a myriad of organisms, interconnected and interacting in complicated ways, shaped by the ever-changing circumstances of their environment and interrelations." Views of Nature includes a chapter on The Nocturnal Wildlife of the Primeval Forest, where Humboldt outlines his idea for how such complex systems should be studied: "Generalization of physical appearances and enumeration of results belong to the study of the Cosmos, which admittedly remains for us an inductive science. But the living description of organisms, of animals and of plants, within the context of their local relationship to the many-faceted surface of the Earth (as a small part of the Earth's collective life) presents the material of that study" (Humboldt, 2014, p. 142).

\subsection{Linking functional traits and environment}

Ecomorphology, the relationship between morphological characteristics of organisms and their ecology, has, ever since Cuvier, provided one of the most widely used methodological frameworks to understand ecology and reconstruct environments of organisms in the past. Palaeoecological research based on comparative ecomorphology in the modern sense goes back several decades (see Barr, 2018). For example, morphology of the skull, dentition and postcranial skeleton in mammals reflects feeding ecology, dietary adaptations and locomotion in different habitats. Browsing ungulates tend to have relatively small skulls with narrow muzzles, shallow jaws, brachydont dentition, large attachment surface for temporalis muscles and small for masseters, and face and nasal areas indicating highly mobile lips, whereas these traits tend to be opposite in grazing ungulates (Janis, 1995; Mendoza et al., 2002). Morphology and proportions of postcranial bones, especially limb bones, in ungulates and carnivorous mammals reflect adaptations to moving in habitats with different vegetation structure, and the distribution of these traits in mammal palaeocommunities can thus be used as an ecometric proxy for vegetation (Kappelman, 1991; Kovarovic and Andrews, 2007, 2011; Polly, 2010; Bishop et al., 2011). In addition to comparative ecomorphological analyses, interpretations of mammal community structure have also been used in palaeoenvironmental reconstruction (Kovarovic et al., 2018). For example, analysing body size 
distribution in mammal communities (cenogram analysis and related methods) serves as a proxy for approximate habitat openness and aridity (Legendre, 1986; Alroy, 2003).

The explicit, quantitative modelling of the relationships between functional traits of organisms and their environments in a more fundamentally Humboldtian spirit has recently been called ecometrics (Eronen et al., 2010a; Polly et al., 2011; Vermillion et al., 2018); for an early example, see Solounias and Dawson-Saunders (1988). Organisms interact with their biotic and abiotic environments via traits. Ecometrics quantifies those interactions by focusing on traits, whose measurable structure is related to their function and whose function interacts directly with local environment. The distribution of functional traits is ultimately controlled by evolutionary change that generates new traits and changes the prevalence of existing ones. At a given time, however, local environmental conditions influence the geographic ranges of species, which determine the composition of local communities, and the distribution of their functional traits. Therefore, if we characterize communities by their functional traits, we capture the most important aspects of their environment; this is the basis for ecometric modelling.

Ecometric models are typically built on present day data, featuring trait distributions of communities of species in relation to climate or vegetation characteristics. They are conceptually similar to, but technically reverse of species distribution modelling in ecology. The main difference from species distribution modelling is that in ecometric modelling the aim is to characterize environments given communities of species, whereas in species distribution modelling the main focus is to predict species occurrence given climate (Elith and Leathwick, 2009; Ovaskainen et al., 2017). This distinction becomes instrumental when analysing the past - the fossil record gives localities and species occurrence at localities, while the climatic conditions are unknown and need to be estimated. The functional trait approach fundamental to ecometric modelling is aimed to be independent of any taxonomic nomenclature (Andrews and Hixon, 2014), emphasizing that the link between present and past climate reconstruction relies on functional traits of fossil animals and plants rather than taxonomic affiliation of their living relatives. This allows integrative analyses across broad spatial and temporal scales. Ecometric models can be used for analyses of the biosphere from biogeographic, palaeoclimatic or evolutionary perspectives. Examples of such studies include analysing continentaland global-scale relationships between animals and their environments (Saarinen, 2014; Barr, 2017; Polly and Head, 2015; Eronen et al., 2010b; Lawing et al., 2012; Liu et al., 2012; Žliobaitè et al., 2016), reconstructing past climates and environmental change (Fortelius et al., 2016; Eronen et al., 2010c; Meloro and Kovarovic, 2013; Wing et al. 2005), and evolutionary contexts of organisms (Eronen et al., 2009; Schnitzler et al., 2017; Sukselainen et al., 2015; Dunn et al., 2015).

Different functional traits have been explored for ecometric analysis. In principle, any aspect of anatomy or physiology that can be measured across some subsets of organisms in a community can potentially act as an ecometric trait. For plants, leaf margins, shapes, size, stomatal counts, and venation structure have been used (e.g. Wolfe, 1995; Royer et al. 2005; Traiser et al., 2005; Peppe et al., 2011; Blonder and Enquist, 2014). For animals, considered traits include measures of hypsodonty and lophs of cheek teeth (Eronen et al., 2010b; Fortelius et al., 2016; Liu et al., 2012; Žliobaitė et al., 2016; Meloro and Kovarovic, 2013; Polly and Head, 2015), limb and ankle bone proportions (Barr, 2017; Polly and Head, 2015), vertebral shape and tail proportions (Lawing et al., 2012), as well as body mass (Head et al., 2009; Meloro and Kovarovic, 2013). In this study, we focus on dental traits of large herbivorous mammals and their relationships to local climate. Previous studies have established a link between herbivore teeth and climate (e.g. Fortelius et al., 2002; Eronen et al., 2010b; Liu et al., 2012; Žliobaitė et al., 2016), but they have primarily focused on precipitation and productivity, or the models have been more tailored for tropical latitudes. The aim of this study is to present new dental ecometric models for predicting climate at temperate latitudes, with a special focus on temperature, which has been difficult to predict so far. We explore the predictive power of these new models with a case study of Pleistocene fossil sites in Europe. 


\subsection{Dental ecometrics: how and why it works}

Teeth can be used for many purposes, but their primary function is effective comminution of foods. Mammalian teeth are special, since they occlude precisely and maintain that occlusion through several stages of tooth wear to enable efficient mastication of structurally challenging foods. The majority of primary production on land is generated by vascular plants, which are particularly challenging to feed on because they are usually difficult to chew, while having relatively poor nutritive value due to presence of hard-to-digest cellulose and lignin (van Soest, 1994), requiring large intakes per day. Plants growing in different climates and over different seasons have different structural properties that require biomechanically different mastication, and teeth need to match those challenges (Sanson, 2006). Locally available vegetation in turn depends on environmental factors, such as temperature, precipitation, seasonality, daylight, soil properties, elevation, and more. Since molars of large herbivorous mammals are adapted to mastication of plant foods available in local environments, the composition of mammalian communities in terms of their dental traits carry information of local environmental conditions (Fortelius et al., 2002).

The proportions of grass vs. non-grass vegetation (browse) present the most distinct biomechanical challenges for large herbivores feeding on structural plant parts (Sanson, 2006). Grass, featuring relatively low chemical and mechanical defenses compared to browse (e.g. Owen-Smith et al., 1993; Lucas, 2004), can be readily ingested in large amounts by large herbivores. However, feeding on large quantities of grass wears teeth quite intensively due to presence of abrasive phytoliths (Lucas et al., 2013; Merceron et al., 2016; Winkler et al., 2019) and dust and grit on plant surfaces (e.g. Damuth and Janis, 2011; Jardine et al., 2012). Therefore, teeth adapted to eating grass, especially in more open habitats, would have to be durable, featuring high-crowned (hypsodont) molars, or thick enamel (Janis and Fortelius, 1988; Kaiser et al., 2013; Damuth and Janis, 2014). Browse, especially mature leaves and stems of woody plants, is particularly difficult to chew due to relatively high toughness, as it often contains large amounts of lignin, which increases the force required to shear fibres (van Soest, 1994). Lignin and some chemical compounds, such as tannins, also reduce digestibility of browse (Owen-Smith et al., 1993), emphasizing mastication over ingestion for browsing herbivores. Efficient mastication of such food requires bladed teeth (Lucas, 2004, p. 121; Žliobaite and Fortelius, 2018). A blade is formed by the wear facets that mark the surfaces of cusps and lophs and is maintained by attrition (Popowics and Fortelius, 1997). Such an emphasis on cutting ability over durability of teeth is typical for herbivorous mammals living in seasonally cold vegetated habitats (e.g. temperate and boreal forests), where available food outside the growing season is mostly limited to structural plant parts with a low amount of abrasives (Liu et al., 2012).

An idea from optimal foraging theory, known as Liem's paradox (Robinson and Wilson, 1998), suggests that consumers are primarily adapted to critical non-preferred foods, which are the only food items available outside the growing season. Dental traits are therefore expected to primarily relate to limiting climatic conditions, as has been found for some ecosystems (Žliobaitè et al., 2016). Net primary productivity (NPP) is a summary of climatic and environmental limits; it measures the amount of chemical energy available for consumers from plants. NPP already accounts for limitations by available solar energy, temperature, precipitation, or soil composition. Therefore, NPP is the proxy that has been globally best predictable by dental traits of large plant-eating mammal communities (Liu et al., 2012). Figure 1 depicts areas in which NPP is primarily limited by temperature and where NPP in turn is primarily limited by precipitation. A general pattern is clear NPP is primarily limited by precipitation in the most habitable terrestrial environments, while in the northern latitudes and places of high elevation, NPP is primarily limited by temperature. Therefore, dental ecometrics is expected to accurately predict precipitation and temperature only regionally, while NPP is well-predicted from dental traits globally. Because of these limits, precipitation can be 
predicted accurately in the tropics, while temperature is much less predictable from dental traits (Fortelius et al., 2016). In the temperate latitudes, where NPP is primarily limited by temperature, we expect temperature to be better predictable from dental traits than precipitation. In the fossil record, of course, the global boundaries of precipitation- and temperature-limited NPP areas might be different, and it remains to be seen how deep past accuracy of dental ecometric patterns of the present day extends. With this in mind, we here develop new ecometric models, particularly focused on predicting temperature, and test them on the Pleistocene fossil sites in Europe, where we expect those temperature models to be applicable and informative.

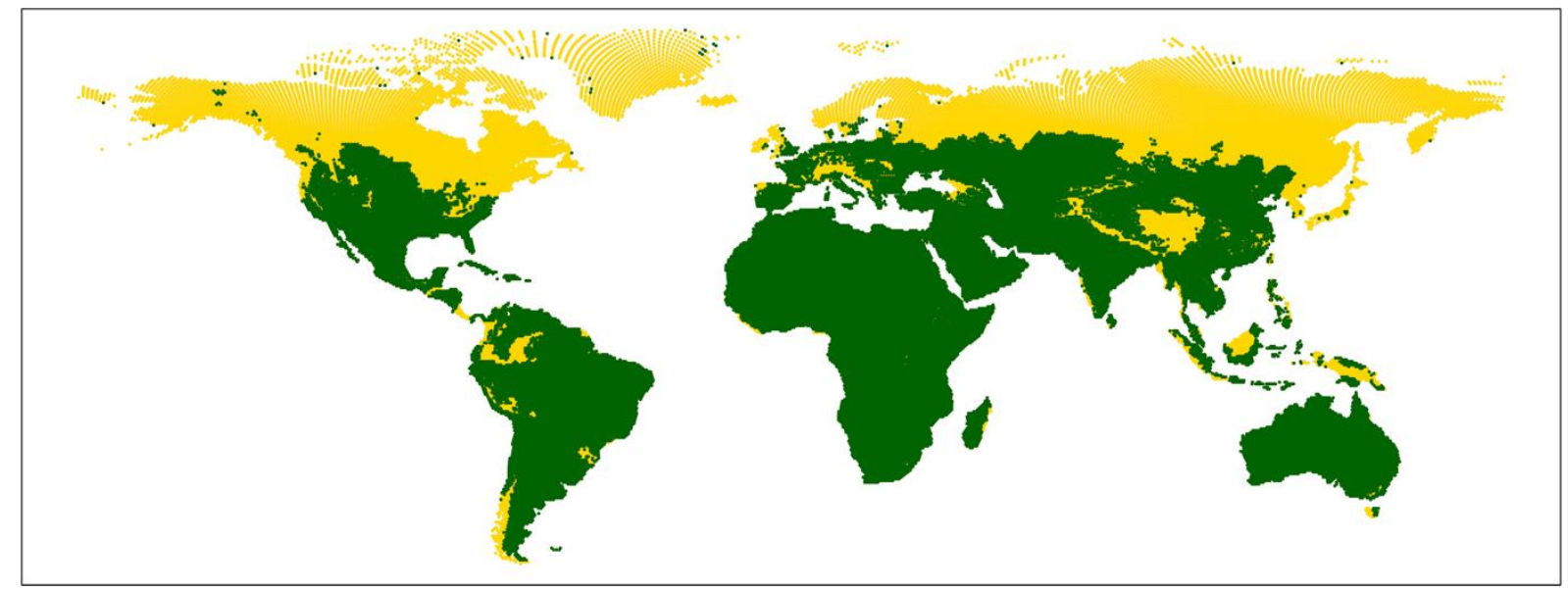

Figure 1. Global map of net primary productivity (NPP) showing areas limited by precipitation (green) and temperature (yellow). The limits are estimated from mean annual temperature (MAT) and mean annual precipitation (MAP) using Lieth's (1975) equations for NPP, as cited by Liu et al. (2012). MAP and MAT data are from Bioclim2 (Fick and Hijmans, 2017). Projection: no map projection was used, plain latitude and longitude coordinates are plotted as points in color on a plain.

\section{MATERIALS AND METHODS}

Typical ecometric studies consist of two steps - building a model on present-day data and applying the model to analyze the past.

\subsection{Dental ecometric models}

Dental ecometrics builds on biomechanical properties of teeth across communities of large herbivorous mammals. Dental ecometric models, like any other ecometric models, require three types of data: species occurrence at localities, plausibly functional traits of those species, and climatic parameters of those localities. For each locality, an average of each dental functional trait is computed over species that occur at that locality. A predictive model is then fit using those average dental traits as inputs and climatic variables (one at a time) as outputs. A predictive model can be of any form, for example, a linear regression model.

The advantage of ecometric methods is their temporal and spatial scaling. While they can give reasonably accurate climatic estimates at the level of localities, they can scale globally, since they are primarily based on species lists, which is non-destructive to the samples, and work with data compilations rather than actual specimens. Typically, ecometric traits are measured from a few specimens per species, assuming that measurements of individuals are representative of entire species. The methodology thus does not require to see every sample at every locality, and allows to work with fossil data, while not all samples in the fossil record need to be teeth. For this to hold, 
traits for ecometric analysis are selected in a way that the expected among species variation is much greater than within species variation or geographic variation (Polly et al., 2017).

The climatic dataset for making the new models is based on bioclimatic variables from Bioclim2 (Fick and Hijmans, 2017), which is a raster dataset from an interpolation of observations coming from weather stations globally, processed as in žliobaite et al. (2018) to $50 \times 50 \mathrm{~km}$ resolution. Global species occurrences were derived from digital geospatial ranges associated with the 2014 IUCN Red List of Threatened Species (IUCN, 2014). Ranges, represented by spatial polygons, were downloaded as shape files. Dental trait data for present day species include hypsodonty scores and loph counts following the NOW database (The NOW Community, 2018), and additional data on acute lophs that we scored specifically for this study. As in previous works on dental ecometrics (e.g. Liu et al., 2012), we define large mammals as those belonging to orders: Artiodactyla, Perissodactyla, Proboscidea and Primates. We used the centroid of $50 \times 50 \mathrm{~km}$ grids laid out across the globe as a sampling scheme for these large mammal assemblages, where each grid cell was assumed to represent a locality (following Polly, 2010). We extracted lists of species occuring at each site. We used the species lists to summarize trait distributions of large mammal assemblages by averaging traits for species that occur within a sampling site. To minimize the risk of ecometric models being distorted by rare and exceptional patterns, we only considered those grid cells that report at least three species, and only those sites, where elevation is less than $2.5 \mathrm{~km}$. Considering that dental traits primarily reflect climatic limits (Žliobaite et al., 2016), theoretically there is no point to force the model to fit extremely high precipitation values, therefore we capped precipitation values for modelling purposes at 3000 mm. Spatial data sets use the Geographic Coordinate System WGS 1984. Modelling datasets and processing code are available on GitHub (https://github.com/zliobaite/Humboldt).

We produced four predictive models for NPP, annual precipitation (MAP), mean annual temperature (MAT) and minimum annual temperature (MINT). MAT, MAP, and MINT are directly from Bioclim variable one, six and twelve (Fick and Hijmans, 2017). NPP is calculated from a combination of MAT and MAP (Lieth, 1975, as cited in Liu et al., 2012):

NPP $=\min [(3000 / 1+\exp (1.315-0.119 \mathrm{MAT})),(3000(1-\exp (-0.000664 \mathrm{MAP})))]$

Following Liu et al. (2012) to separate the effects of each dental variable for predicting NPP and MAP, we used assemblage mean hypsodonty (HYP) and mean longitudinal loph count (LOP) as input variables. For MAT and MINT, we used mean presence of acute lophs (AL) as an input. We fit linear regression via ordinary least squares, which gave the following models:

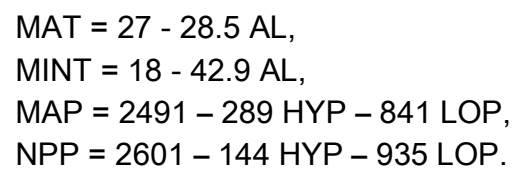

For comparison, Liu et al. (2012) models, which used different input variables for temperature and a different data source (ecoregions) for species occurrence, are:

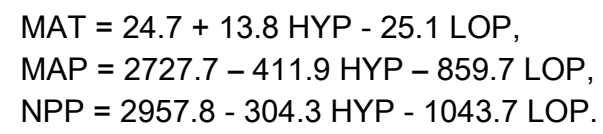

Additional information about model selection, fitting and validation is given in Appendix S1 in supplementary information (see Table S1.1 for model fit and variance statistics). 


\subsection{Dental traits and their predictive power}

\subsubsection{Hypsodonty and longitudinal loph count}

It is well established that the average tooth crown height (hypsodonty) and the mean number of longitudinal lophs (LOP) together accurately capture NPP at the global, as well as regional scales (Liu et al., 2012; Fortelius et al., 2016). We can see in Figure 2 that the colour gradient of mean hypsodonty (HYP) at present day closely matches those of NPP and MAP in the tropics. Although the magnitude of HYP is much lower in the temperate latitudes, its polarity still follows the MAP gradient (Figure 2). The longitudinal loph count (LOP) does not lose magnitude in the temperate latitudes, but it lacks resolution compared to hypsodonty in the tropics. Because HYP and LOP are strongly correlated, especially in the tropics, both variables have been used as an approximation for modelling NPP and MAP at the global scale (Liu et al., 2012). However, HYP has a relatively higher weight in Liu et al. (2012) models than in the new models. One of the reasons for this is that ecoregions (used as units of analysis by Liu et al., 2012) are of different sizes, being much larger in the northern latitudes, thus giving relatively less weight for the north in the global fit. In other words, NPP and MAP models of Liu et al. (2012) are slightly more tailored for the tropical areas than the new models. 


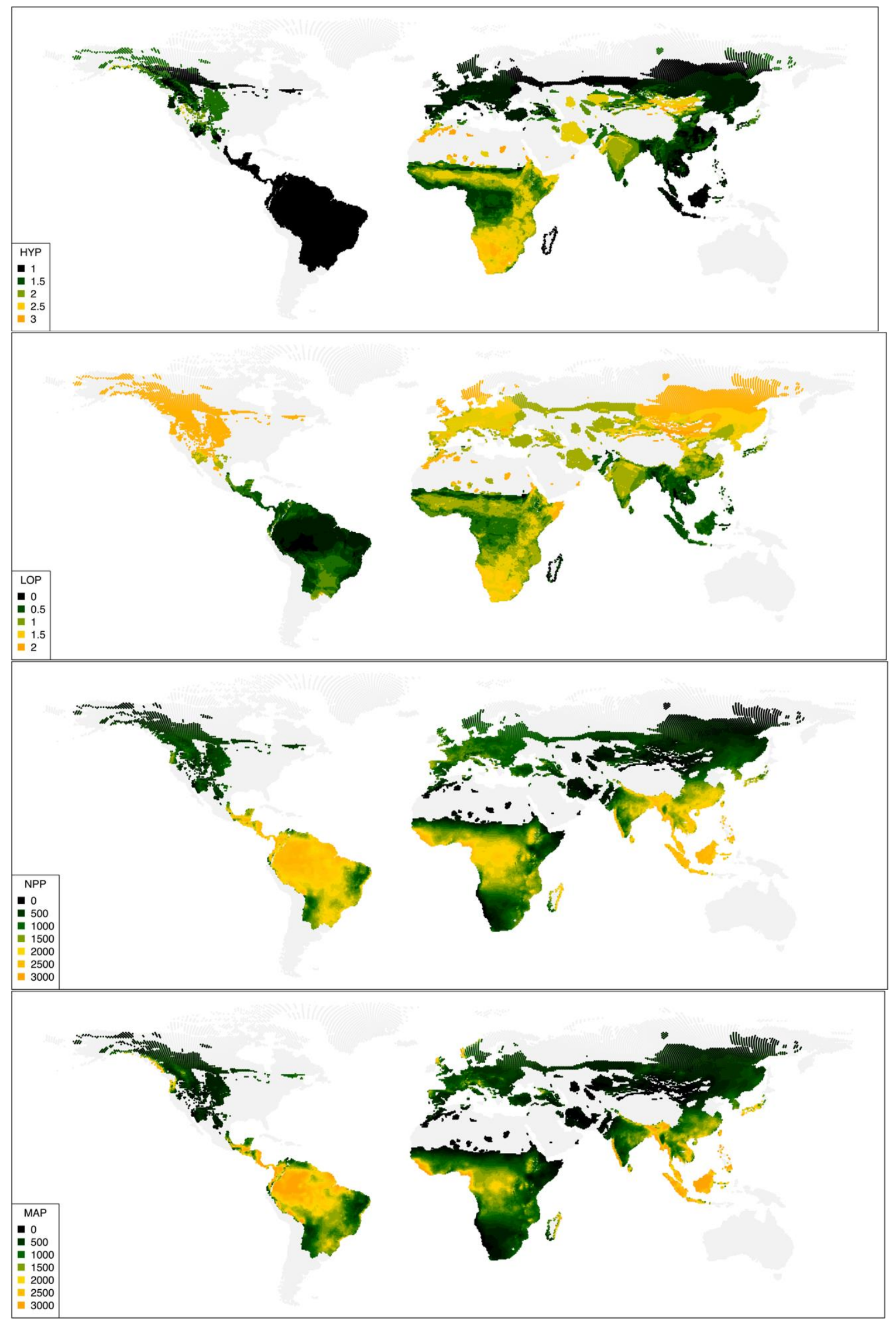

Figure 2. Hypsodonty (HYP) and loph count (LOP), net primary productivity (NPP) ( $\mathrm{g} \mathrm{C} \mathrm{m}^{-2}$ year-1 dry matter) and precipitation (MAP) ( $\mathrm{mm}$ per year). The units of analysis are grid cells of $50 \times 50 \mathrm{~km}$. Only areas that have at least three species of large plant eating mammals (orders: Artiodactyla, Perissodactyla, Proboscidea and 
Primates) are reported. MAP and MAT data are from Bioclim2 (Fick and Hijmans, 2017), NPP is computed from MAT and MAP using equations from Lieth (1975) as reported by Liu et al. (2012). Projection: no map projection was used, plain latitude and longitude coordinates are plotted as points in color on a plain.

\subsubsection{Acute lophs}

Whereas hypsodonty reflects dental durability (e.g. Janis and Fortelius, 1988; Damuth and Janis, 2011), presence of lophs on the occlusal surface of a tooth coarsely reflects cutting ability based on the association of loph count and a highly fibrous diet (Jernvall et al., 1996). Liu et al. (2012) found a good correlation between present day LOP count and mean annual temperature. They postulated a link between cutting ability in herbivore teeth and temperature based on herbivore communities in the northern ecoregions being characterized by high LOP and low HYP, which implies high functional demand without increased tooth wear. However, they also found that LOP alone cannot distinguish between warm and cool low-productivity biomes, but HYP, being lower in cool (and therefore moist) biomes, does resolve them. This suggests a non-linear relationship with LOP and temperature. Indeed, LOP is high when species with longitudinal lophs dominate the community, while no species with transverse lophs are present (e.g. proboscideans) and no bunodont species are present (most primates and pigs). LOP in some sense acts as a taxonomic proxy, putting an emphasis on equids, bovids and cervids compared to the rest. Exclusive presence of those groups leads to high average LOP and tends to signal harsh environments, which can be arid (steppe and semi-desert) or moist, but cold (boreal forest and tundra).

LOP was used by Liu et al. (2012) as a measure of cutting ability due to absence of a more precise scoring scheme at the time. LOP cannot distinguish between browsers and grazers, which might suggest that grass and browse have similar functional relationships with herbivore teeth; this is not the case, however. To better reflect the theoretical reasoning outlined in Liu et al. (2012), we here experiment with acute lophs for estimating temperature. Acute lophs are defined as having a single, distinct edge, and only if the leading enamel itself forms a sharp edge, or supports a distinct, planar wear facet (Žliobaite et al., 2016). By convenience, until the present study, all selenodonts have been scored as having obtuse lophs due to difficulties in distinguishing between the two crown types in combination with selenodont tooth morphology and variations due to wear stages. Here we make a scoring distinction between acute and obtuse selenodont lophs. We do not change the original functional crown type scoring scheme (Žliobaitè et al., 2016), but add new information on how to score selenodonts.

For scoring acute lophs, the dominant upper molar is scored. $\mathrm{M} 2$ is scored for most species, except for species whose dominant molar is either M1 or M3 (e.g. M3 for some suids), then that tooth is scored instead of M2. Scoring of acute lophs for selenodonts is based on three (non-universal) criteria:

1. Distribution of enamel ridges over the occlusal surface (space) - acute lophs would come with a widely spaced central cavity at mid-wear, while non-acute lophs would have a wider spacing at cusps (in Archer and Sanson, 2002, the former would the the space between R2$\mathrm{R} 3$, and the latter would be the space between R1-R2, R3-R4).

2. The shape of the crown - pyramid shaped teeth at mid-wear are scored as acute. Hypsodonty is also correlated as acute lophs almost never have hypsodont molars (except for notoungulates, which accomodate hypsodont molars by their upper teeth being buccolingually crooked).

3. As a last resort, we look at the mesowear relief per species (Fortelius and Solounias, 2000), in which high relief would typically correlate with presence of acute lophs. 
Figure 3 gives examples, following the functional crown type scoring scheme (Žliobaitè et al., 2016), reflecting the refined scoring of selenodonts. In the current study we only use the acute loph type (the temperature model uses the fraction of species that have acute lophs over the total number of species present at a locality). Scores for living and fossil species of our case study are given in Appendix S2 (Table s S2.2 and S2.3, respectively). Figure 4 gives the distribution of acute loph scores for all large plant-eating mammals, which include selenodonts, and mean annual temperature.

Visually the match is quite close, which explains a relatively high model fit for predicting the mean annual temperature.

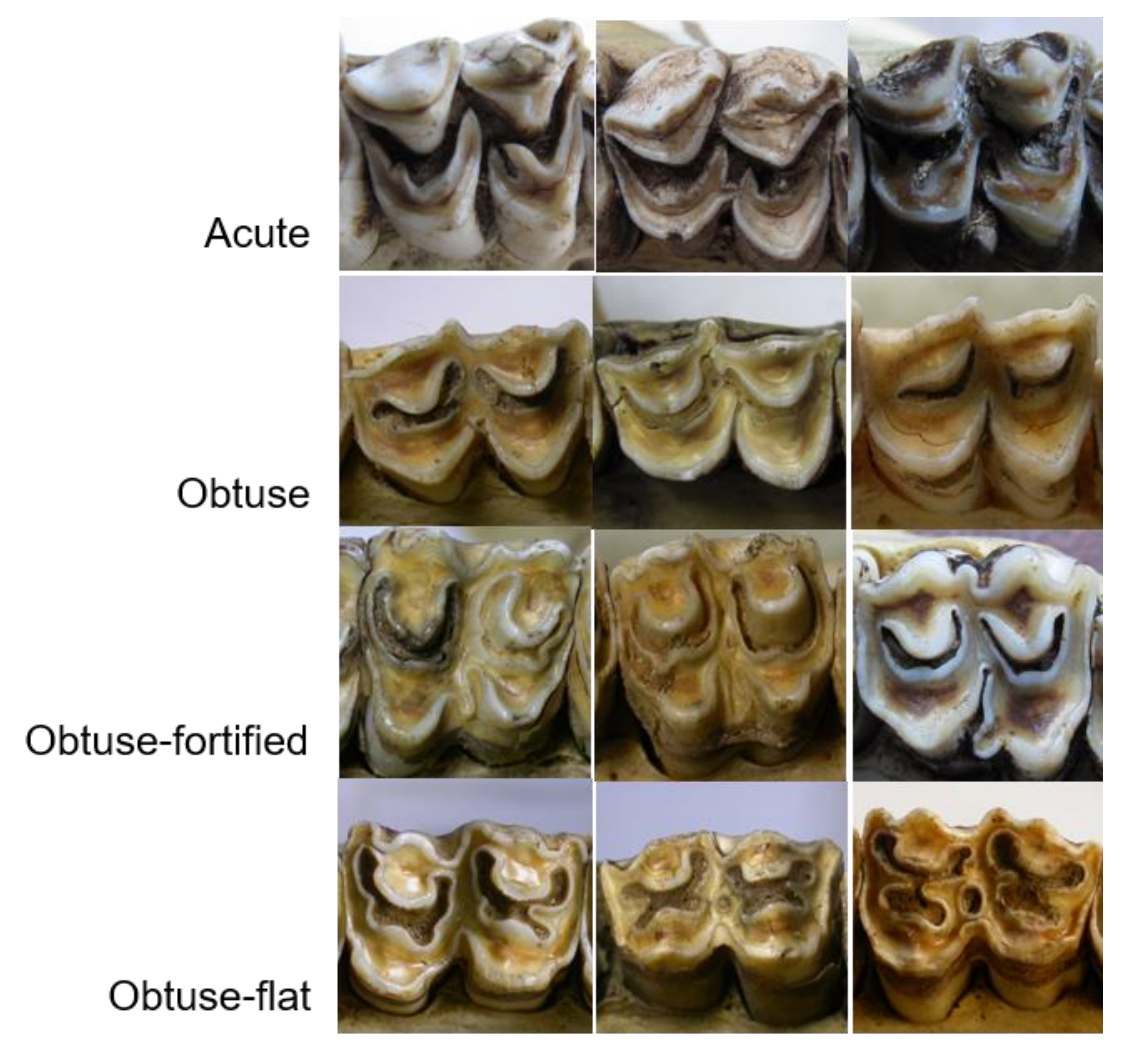

Figure 3. Acute, obtuse and other loph types in selenodonts. (Photo credit: Elina Hernesniemi)

Species from left to right: Blastoceros dichotomus, Giraffa Camelopardalis, Mazama chunyi (top row); Aepyceros melampus, Capra ibex, Gazella dorcas (upper second row); Kobus leche, Redunca arundinum, Cephalophus callipygus (third row); Alcelaphus buselaphus, Connochaetes gnou, Damaliscus lunatus (bottom row). 


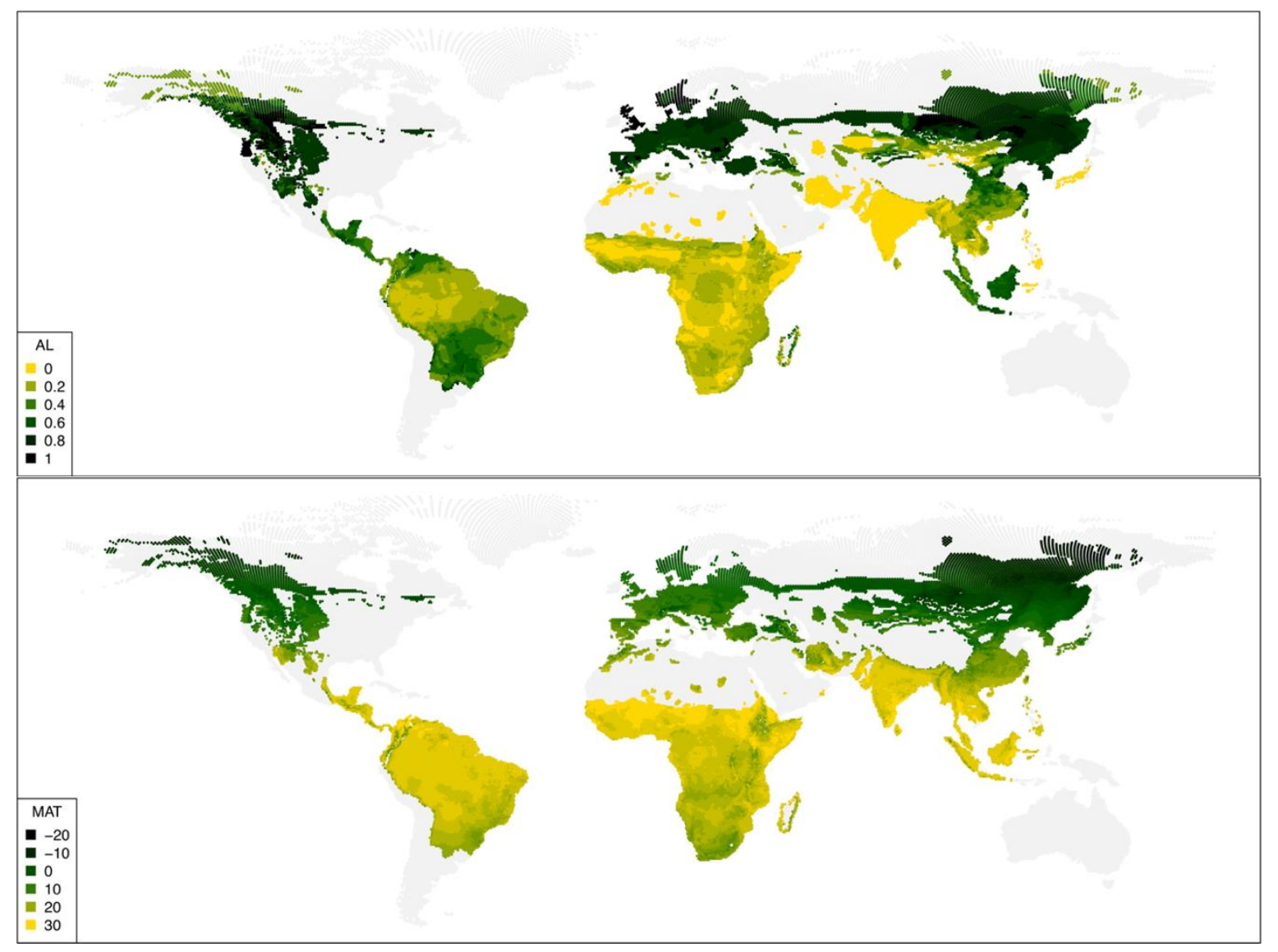

Figure 4. Distribution of acute lophs (AL) in Artiodactyla, Perissodactyla, Primates and Proboscidea, and mean annual temperature (MAT) across grid cells of $50 \times 50 \mathrm{~km}$. Projection: no map projection was used, plain latitude and longitude coordinates are plotted as points in color on a plain.

\subsection{An ecometric analysis of Pleistocene fossil sites in Europe}

The Pleistocene started when a global cooling trend of the late Pliocene had reached a point after which periodical glaciation events started in the Northern hemisphere, following cyclic changes in the orbit and axis orientation of the Earth (Walker and Lowe, 2007). Since then, the climate oscillated between the extremes of cold glacial maxima and warm interglacial stages in the Northern hemisphere. The cyclic changes in Pleistocene climate caused particularly drastic changes in biome distributions and environments of Europe. There was a general shift during the Early Pleistocene from forests to partly open wooded environments, especially during the cool climatic phases in Europe. This can be seen, for example, in England, where the dominant warm-phase environments were temperate forests, but were largely replaced by boreal woodland-grassland-heathland mosaics during cool climatic phases (West, 1980). Local differences between cold phase and warm phase environments were further intensified later, during late middle and especially late Pleistocene, when large continental ice sheets in Northern Europe periodically blocked moisture from reaching the continental interior, they caused dry and cool climatic conditions and open steppe-tundra environments (mammoth steppes) to spread in Europe (Guthrie, 2001).

We test the new models to estimate MAT, MINT and NPP for 50 relatively well-studied Early and Middle Pleistocene fossil sites (Appendix S2, Table S2.4) in Central, Western and Southern Europe, which have a qualitative overview on Pleistocene palaeoenvironments based on large mammal faunas (Kahlke et al., 2011). Where available, the ecometric estimates for individual sites are compared with other proxies for a given site. We have sorted sites to three-time intervals based on 
Gibbard et al. (2010): Early Pleistocene I (2.6-1.8 Ma ago), Early Pleistocene II (1.8-0.78 Ma ago) and Middle Pleistocene (0.78-0.126 Ma ago). The time intervals are coarse, but they enable a larger sample size because most of the fossil sites in Europe lack precise age estimates. Dental traits for the fossil sites (Appendix S2, Table S2.3) were scored specifically for this study using published images and our own fossil images. In rare cases where no images for species were available, a dominant score for a genus or family was assigned. The sites, their respective faunal lists and their dental trait scores will be made available in the NOW database upon publication of this study (http://www.helsinki.fi/science/now/).

\section{RESULTS}

\subsection{Ecometric palaeoclimate estimates}

Ecometric predictions of mean annual temperature (MAT) and net primary productivity (NPP) for the fossil sites are summarized in Figure 5. Minimum temperature is not shown here, since the predictions, originating from the same dental trait as MAT, show similar patterns. A detailed summary for individual sites, including dental traits and ecometric estimates, is given in Appendix S2 (Table S2.4).

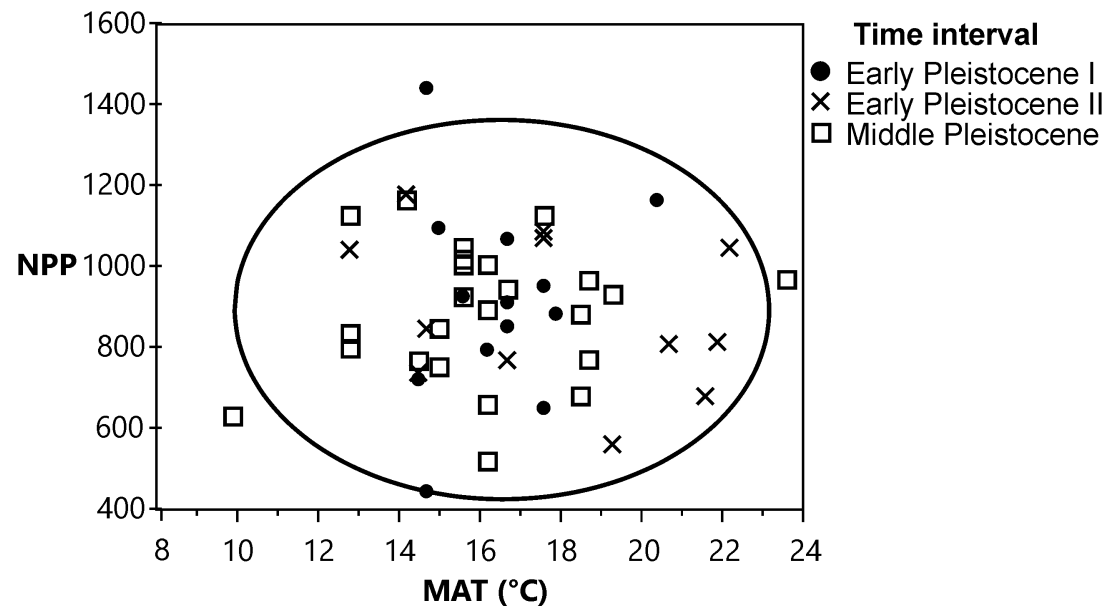

Figure 5. Net primary productivity (NPP) (as $\left.\mathrm{gCm}^{-2} \mathrm{yr}^{-1}\right)$ and mean annual temperature (MAT) at the fossil sites included in this study. The $95 \%$ confidence ellipse was calculated from the entire sample $(\mathrm{N}=50)$.

While visually Early Pleistocene I seems to have slightly higher productivity than the subsequent time intervals, and Early Pleistocene II seems to be somewhat on the higher temperature end, no large directional trends of climate change appear from the estimates over those three time intervals. This is not surprising, considering the large time intervals likely containing several climate cycles. However, temporal patterns in dispersion can be observed.

A closer inspection of the patterns in Figure 5 suggests that differences in temperature between individual sites tend to be smaller for the oldest time interval (Early Pleistocene I) compared to the younger intervals, which is also indicated by lower variance in MAT compared to the other time intervals (Table 1). This could indicate relatively stable climatic conditions during the first half of the Early Pleistocene, which are in line with relatively low fluctuations in global climate before the midPleistocene transition (e.g. Mudelsee and Stattegger, 1997; Zachos et al., 2001). Wider range of MAT estimates, especially during the second half of the Early Pleistocene (Table 1), could in turn indicate increased temporal or regional differences in climate, or both, since the spatial coverage of the sites is more or less consistent over time (Figure 6). Nevertheless, most of the sites in Figure 5 tend to cluster in the middle, indicating similar environmental conditions. 
Table 1. Means and variances of mean annual temperature (MAT) and net primary productivity (NPP) for the time intervals of the case study.

\begin{tabular}{llllll}
\hline Time interval & $\mathbf{N}$ & MAT (mean) & MAT (var) & NPP (mean) & NPP (var) \\
\hline $\begin{array}{l}\text { Early } \\
\text { Pleistocene I }\end{array}$ & 13 & 16.5 & 2.8 & 914.5 & 62110.4 \\
$\begin{array}{l}\text { Early } \\
\begin{array}{l}\text { Pleistocene II } \\
\text { Middle }\end{array}\end{array}$ & 13 & 17.6 & 10.8 & 881.9 & 34040.4 \\
\begin{tabular}{l} 
Pleistocene \\
\hline
\end{tabular} & 24 & 16.1 & 7.6 & 885.6 & 27640.9 \\
\hline
\end{tabular}
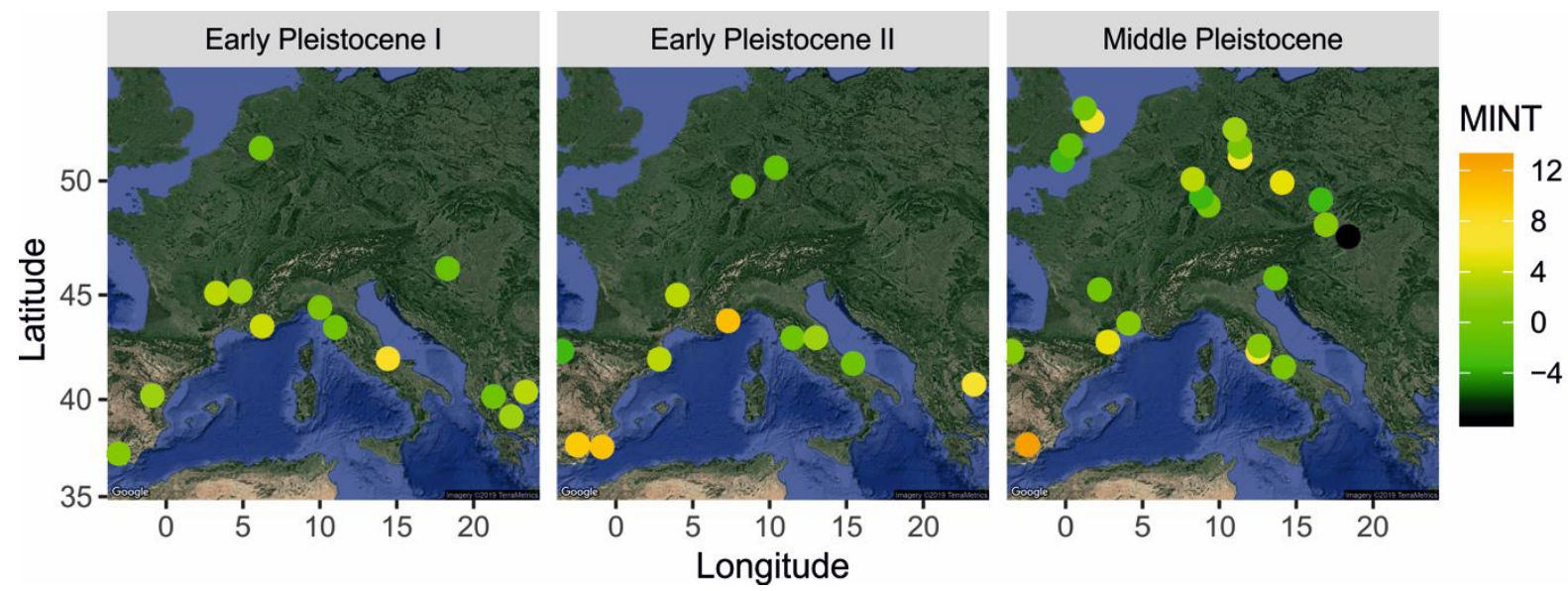

Figure 6. Geographic location of the fossil sites per time interval and their ecometric estimates of mean temperature of the coldest month (MINT). Projection: Google Maps satellite imagery with a Spherical Normal (equatorial) variant of the Mercator projection.

\subsection{Implications of freezing}

Estimates of the mean minimum temperature (MINT) can give a perspective towards the seasonality of climate, and whether water could have been regularly freezing during the cold season. Freezing presents a state shift for the environment, particularly for plants, many of which are deciduous, but also for the fauna, if snow coverage is regularly expected. According to our estimates of MINT (Table 2), Early Pleistocene I does not seem particularly warm or cold; the lowest estimates being slightly below zero do not indicate particularly harsh winters, but probably cold enough for the occasional snowfall during the winter. The estimates for Early Pleistocene II indicate a relatively warm period, despite some sites having lower MINT estimates compared to Early Pleistocene I. This is supported by the occurrence of Hippopotamus at over half of our sites in this period (Table 2).

Among individual taxa, Hippopotamus, due to its habitat requirements, is an important climate indicator. Although the occurrence of Hippopotamus does not necessarily indicate a particularly warm climate, it at least indicates a relatively mild winter due to its amphibious lifestyle. With that being said, most of the sites with Hippopotamus coincide with MINT estimates above zero, as would be expected (Table 2). Still, there are some exceptions, especially the Middle Pleistocene site of Mauer, which seems to have been a bit too cold to support Hippopotamus based on our estimates, but apparently this was not the case. However, the relatively cold signal from Mauer suggests that it was a rather marginal environment for Hippopotamus in Europe. Overall, a more sporadic 
occurrence of Hippopotamus compared to Early Pleistocene II, combined with the lowest MINT estimates, suggests relatively cool, although variable climatic conditions during the Middle Pleistocene.

Table 2. Ranking of sites according to the minimum temperature estimates. Freezing sites are highlighted in bold. Sites with inferred occurrence of Hippopotamus are marked with *.

\begin{tabular}{|c|c|c|c|c|c|}
\hline \multicolumn{2}{|l|}{ Early Pleistocene I } & \multicolumn{2}{|l|}{ Early Pleistocene II } & \multicolumn{2}{|l|}{ Middle Pleistocene } \\
\hline Site & MINT & Site & MINT & Site & MINT \\
\hline Villány 3 & -0.9 & TD6, Atapuerca & -3.4 & Vértesszölös 2 & -7.7 \\
\hline Dafnero & -0.4 & Untermassfeld* & -1.3 & Stránská Skála I & -3.4 \\
\hline Tegelen & -0.4 & Dorn-Dürkheim 3 & -0.9 & Boxgrove & -3.4 \\
\hline Montopoli & 0 & Pirro Nord & -0.4 & Mauer* & -3.4 \\
\hline Olivola & 0.8 & Pietrafitta & -0.4 & Swanscombe & -1.3 \\
\hline Fonelas & 1.7 & Colle Curti* & 2.6 & Visogliano & -0.9 \\
\hline Saint Vallier & 2.6 & Sainzelles* & 3.8 & West Runton & 0 \\
\hline Sesklon & 2.6 & Incarcal $1^{*}$ & 3.8 & La Fage & 0 \\
\hline La Puebla de Valverde & 2.6 & Apollonia & 6.4 & Voigtstedt & 0.8 \\
\hline Chilhac & 3.8 & Fuente Nueva $3 *$ & 8.6 & Steinheim & 0.8 \\
\hline Gerakarou 1 & 3.8 & Venta Micena* & 9.8 & Isernia La Pineta* & 0.8 \\
\hline Seneze & 4.3 & Cueva Victoria & 10.3 & TD8, Atapuerca* & 0.8 \\
\hline \multirow[t]{12}{*}{ Coste San Giacomo* } & 8.1 & Vallonnet* & 10.7 & Hundsheim & 1.7 \\
\hline & & & & Lunel-Viel & 1.7 \\
\hline & & & & Cesi* & 1.7 \\
\hline & & & & G III, Atapuerca & 1.7 \\
\hline & & & & Schöningen & 2.6 \\
\hline & & & & Mosbach $2^{*}$ & 3.8 \\
\hline & & & & Koneprusy C718 & 5.1 \\
\hline & & & & Caune de I'Arago & 5.1 \\
\hline & & & & Pakefield* & 5.6 \\
\hline & & & & Süssenborn & 5.6 \\
\hline & & & & Ponte Galeria 2B* & 6.4 \\
\hline & & & & Cúllar de Baza 1 & 12.9 \\
\hline
\end{tabular}

\subsection{Comparison with alternative existing proxies}

Figure 7 presents comparisons of palaeotemperature estimates at selected localities using alternative existing proxies. For these comparisons, we chose fossil localities for which previously published estimates of mean annual temperature (MAT) and temperature of the coldest month (MINT) existed. Estimates based on the present common climatic ranges of ectothermic vertebrate species in the fossil assemblages were available for the following localities: West Runton Freshwater bed (Böhme, 2010), Tegelen (Villa et al., 2018), Fuente Nueva 3 (Blain et al., 2011), Cueva Victoria (Blain et al., 2008) and Atapuerca TD6 (Blain et al., 2009). Estimates based on mutual climatic ranges of fossil beetles (Coleoptera) were available for West Runton Freshwater bed (Coope, 2010) and Pakefield (Hosfield, 2016 and references therein). Mutual ostracod temperature ranges were used for Boxgrove (Hosfield, 2016 and references therein) and Swanscombe (White et al., 2013).

The palaeotemperature estimates based on dental ecometrics of fossil herbivorous mammal assemblages are generally similar to the estimates based on other proxies (Figure 7). The MAT estimates from dental ecometrics are consistently between ca. $1^{\circ} \mathrm{C}-6^{\circ} \mathrm{C}$ higher than from the other proxies, with the largest difference being $8{ }^{\circ} \mathrm{C}$ for West Runton Freshwater Bed. However, the dental ecometric estimates of MAT closely track the ones obtained from other proxies and are significantly positively correlated $\left(R^{2}=0.64, p=0.03\right)$ in the case of multiple proxy comparisons (Figure $\left.7 a\right)$. The MINT estimates from dental ecometrics are even closer to the estimates obtained from other 
proxies, differing on average only by $0.5^{\circ} \mathrm{C}$ to ca. $2^{\circ} \mathrm{C}$, with the largest difference being ca. $6{ }^{\circ} \mathrm{C}$ for Pakefield and Atapuerca.

(a)
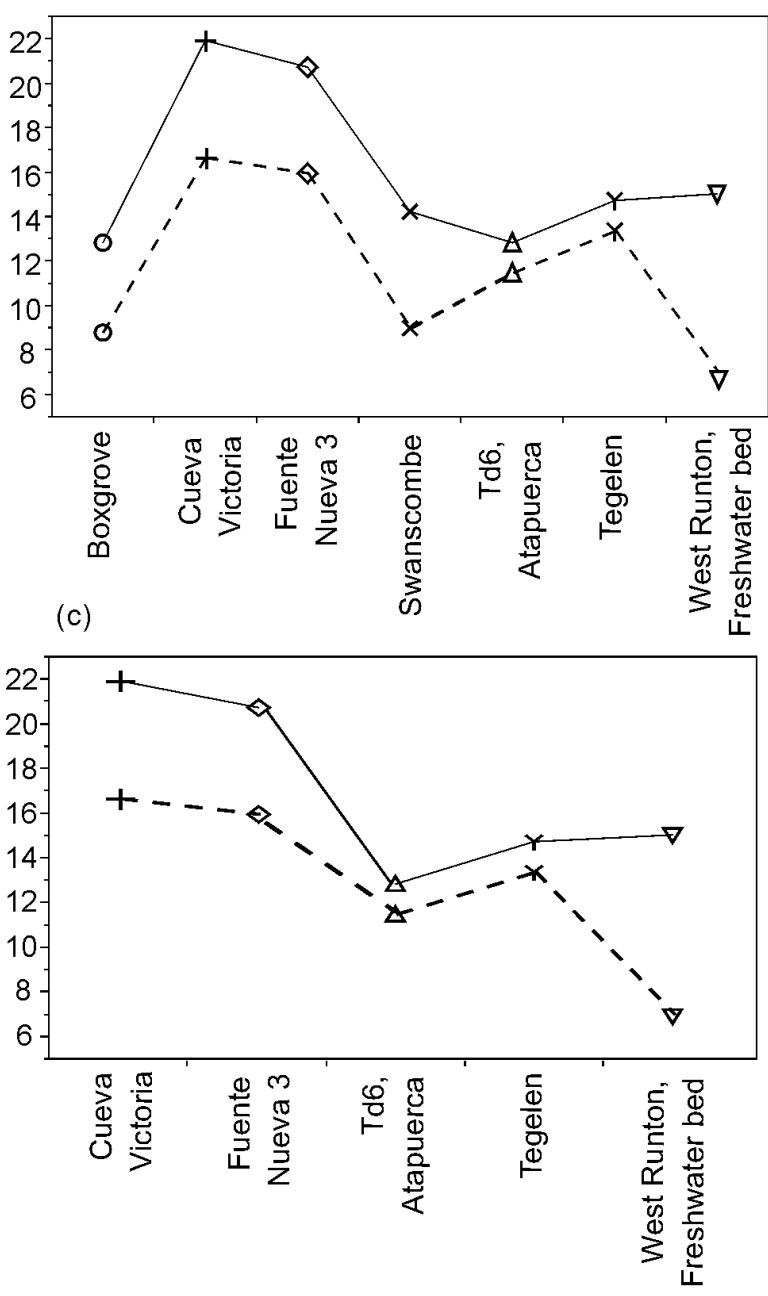

(b)
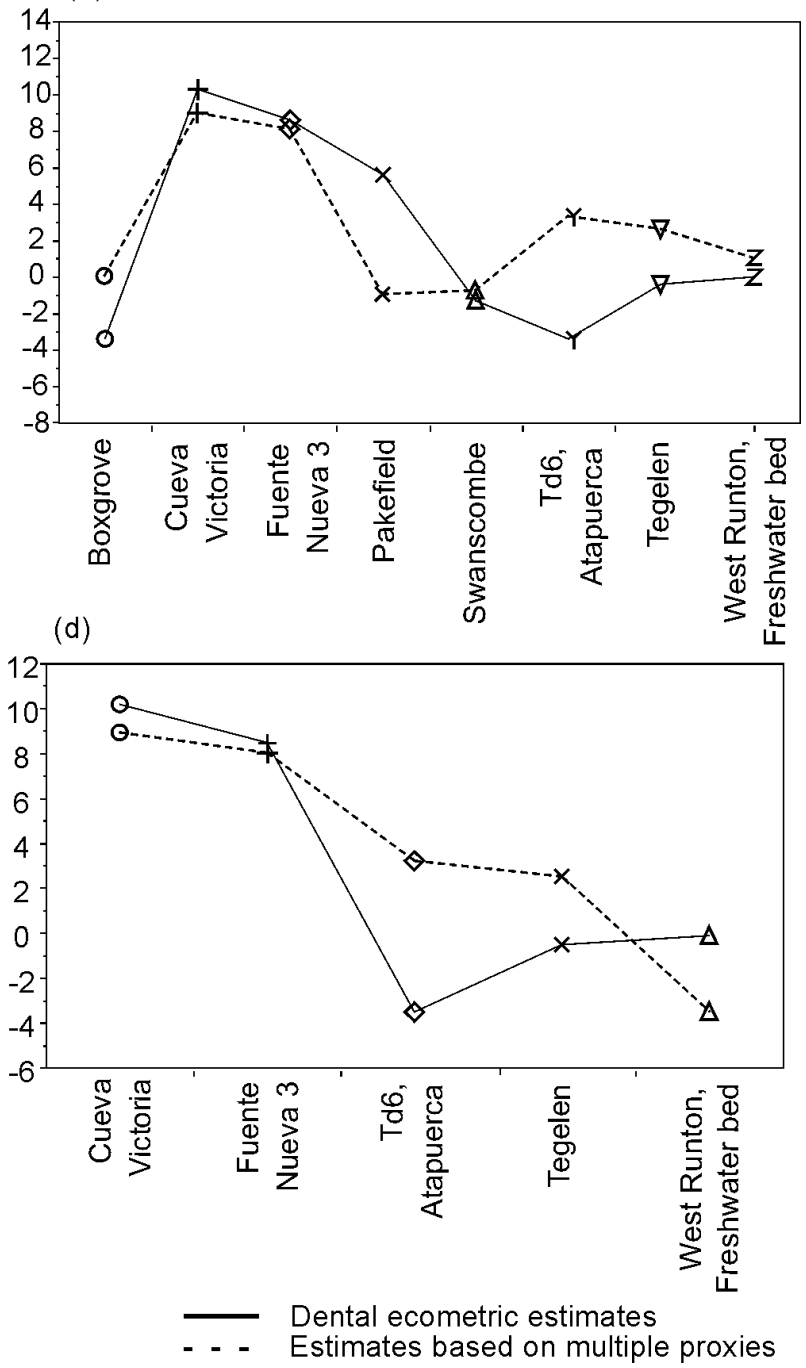

Figure 7. Comparison of palaeotemperature estimates at selected localities using different proxies.

(a) Mean annual temperature (MAT) as estimates from dental ecometrics of mammals (solid line) and from multiple proxies (mutual climatic ranges of Coleoptera, ectothermic vertebrates, Ostracoda and Mollusca) (dashed line). (b) Minimum annual temperature (MINT) as estimates from dental ecometrics of mammals (solid line) and from multiple proxies (mutual climatic ranges of Coleoptera, ectothermic vertebrates, Ostracoda and Mollusca) (dashed line). (c) Mean annual temperature (MAT) as estimates from dental ecometrics of mammals (solid line) and from mutual climatic ranges of ectothermic vertebrate species (dashed line). (d) Minimum annual temperature (MINT) as estimates from dental ecometrics of mammals (solid line) and from mutual climatic ranges of ectothermic vertebrate species (dashed line).

\section{DISCUSSION}

Palaeoclimate reconstruction is one of the most critical ingredients for present day palaeontological studies. Knowing the climatic context allows us to reason about patterns and trends of the past, as well as evolutionary processes in general. Yet few alternative options for palaeoclimate reconstruction are available. Ocean and atmospheric proxies usually give one or a few global curves, that lack time and spatial resolution for analyses of palaeoenvironmental contexts. Faunal community-based models, such as developed in this study, even lacking precision at times, but 
tailored to work with fragmented data such as that of the fossil recod, can give invaluable locally resolved predictions that allow comparisons between sites.

\subsection{Interpretations of palaeoenvironments}

When it comes to making interpretations on what types of environments the fossil sites represent based on the predictions, the MAT estimates alone cannot distinguish them, as they overlap with the values reported for many biomes based on Zheng et al. (2003), including temperate forests and woodlands, but also grasslands and shrublands. On the other hand, the NPP values, excluding outliers, range between $440-1200 \mathrm{gCm}^{-2} \mathrm{yr}^{-1}$, which are in the range of temperate forests and woodlands, while being consistently higher than the values reported for grasslands and shrublands (Zheng et al., 2003). This is corroborated by pollen evidence for several sites, indicating mostly temperate broadleaf or mixed forests and woodlands (Table 3). Beyond this vegetation signal, however, there is too much overlap between forest types to distinguish them based on dental ecometrics, therefore these estimates, just like estimates from other proxies, should be treated as approximations rather than exact sensors of past climate.

Differences in ecometric estimates between some sites can instead reflect different depositional environments. For example, lakeshore and floodplain environments can promote marshlands, which may function as a buffer against regional environmental change. This is likely the case at Schöningen, a German Middle Pleistocene site, where pollen evidence from channel II indicates noticeable vegetational change from a temperate broadleaf forest to a more open woodland (e.g. Urban and Bigga, 2015), while most of the herbivore species occur throughout the different stratigraphic levels (van Kolfschoten, 2014).

Table 3. Comparison of dental ecometric estimates and vegetation based on pollen description for selected fossil localities.

\begin{tabular}{|c|c|c|c|c|}
\hline Locality & MAT & NPP & Vegetation & Reference \\
\hline Colle Curti & 16.7 & 767 & $\begin{array}{l}\text { Temperate coniferous } \\
\text { woodland }\end{array}$ & Bertini, 2000 \\
\hline Coste San Giacomo & 20.4 & 1163 & Mixed thermophilic forest & Bellucci et al., 2014 \\
\hline Pietrafitta & 14.7 & 845 & $\begin{array}{l}\text { Broadleaf forest } \\
\text { characterized by Quercus, } \\
\text { Liquidambar \& Carya }\end{array}$ & $\begin{array}{l}\text { Manzi et al., } 2011 \text { and } \\
\text { references therein }\end{array}$ \\
\hline Pakefield & 18.7 & 966 & $\begin{array}{l}\text { Mixed forest characterized } \\
\text { by Pinus, Ulmus and } \\
\text { Quercus }\end{array}$ & $\begin{array}{l}\text { Candy et al., } 2006 \text { and } \\
\text { references therein }\end{array}$ \\
\hline Schöningen, channel II deposits & 16.7 & 944 & $\begin{array}{l}\text { Broadleaf forest, replaced } \\
\text { by open woodland }\end{array}$ & Urban and Bigga, 2015 \\
\hline Vallonnet, complex III & 22.2 & 1045 & $\begin{array}{l}\text { Open Mediterranean } \\
\text { woodland, undergrowth } \\
\text { dominated by Cichorieae }\end{array}$ & $\begin{array}{l}\text { Renault-Miskovsky and } \\
\text { Lebreton, } 2006\end{array}$ \\
\hline Visogliano & 14.5 & 767 & Broadleaf forest & Cattani et al., 1991 \\
\hline Voigstedt & 15.6 & 925 & Mixed forest & Erd, 1965 \\
\hline West Runton, freshwater bed & 15 & 847 & Mixed woodland & Field and Peglar, 2010 \\
\hline
\end{tabular}

\subsection{Performance of the new temperature models}

Predicting temperature from dental traits has been challenging up to now, perhaps because aridityrelated dental traits (such as hypsodonty) tend to dominate dental morphology of large herbivores. In this study we managed to resolve acute lophs, which have been expected to carry a temperature signal in relation to the presence of deciduous vegetation, as hinted by Liu et al. (2012), but up until now have been difficult to score, particularly for selenodonts (Žliobaitè et al., 2016). We have shown 
here that, although difficult to score, acute loph distribution can be highly informative about temperature conditions, particularly in the temperate latitudes.

In our fossil case study, MAT and MINT have a strong negative linear correlation with mean AL (Table 4). This is not surprising, as both models are based on acute lophs as an input. Similarly, mean and minimum temperature generally follow a latitudinal gradient, while ecometric temperature estimates are positively correlated with mean HYP and species count $(p<0.0001$ and $p=0.0056$, respectively), by being negatively correlated with mean AL.

Table 4. Pairwise linear correlations between selected dental traits of communities, ecometric estimates, and species count at the fossil sites included in this study $(N=50)$. The high correlation between NPP estimate and LOP is because LOP comes with much higher weight than HYP in the NPP model, Equation (5), so the prediction primarily comes from LOP count.

\begin{tabular}{lrrrrrrr}
\hline & $\begin{array}{r}\text { Species } \\
\text { count }\end{array}$ & $\begin{array}{r}\text { Mean } \\
\text { HYP }\end{array}$ & $\begin{array}{r}\text { Mean } \\
\text { LOP }\end{array}$ & $\begin{array}{r}\text { Mean } \\
\text { AL } \text { (estimate) }\end{array}$ & $\begin{array}{r}\text { MAT } \\
\text { (estimate) }\end{array}$ & $\begin{array}{r}\text { NPP } \\
\text { (estimate) }\end{array}$ \\
\hline Species count & 1.00 & & & & & & \\
Mean HYP & 0.06 & 1.00 & & & & & \\
Mean LOP & -0.16 & 0.48 & 1.00 & & & & \\
Mean AL & -0.39 & -0.65 & 0.10 & 1.00 & & & \\
MAT & 0.39 & 0.65 & -0.10 & -1.00 & 1.00 & & \\
MINT & 0.39 & 0.65 & -0.10 & -1.00 & 1.00 & 1.00 & \\
NPP & 0.14 & -0.58 & -0.99 & 0.00 & 0.00 & 0.00 & 1.00 \\
\hline
\end{tabular}

Mean HYP emerges as a strong counterweight to mean AL (Table 4), naturally because most of the species with acute lophs do not have high-crowned (hypsodont) molars. The vegetation associated with herbivore communities characterized by high mean hypsodonty likely has a significant component of abrasive, drought-resistant grass. The question remains to what extent this type of vegetation coincides with higher temperatures compared to more closed and humid environments.

This is certainly the case in Africa; tropical rainforests and montane forests with higher mean AL and lower mean HYP values compared to savannas (Žliobaite et al., 2016) have lower temperatures due to not only evapotranspiration (Alkama and Cescatti, 2016), but also altitude in the case of montane forests. The situation is more complicated in Europe, and much of this complication stems from the fact that abundance of grass has more to do with aridity than temperature (Guthrie, 1990, p. 213). With that being said, high temperature estimates coupled with relatively high mean HYP values are plausible in a Mediterranean climate characterized by hot summers and mild winters, which was established in southern Europe during the Early Pleistocene ca. 2.3 Ma ago (Suc, 1984), and even occasionally reached northwest Europe (Candy et al., 2006).

On the other hand, our models would likely overestimate temperature for arid environments influenced by continental climate. An extreme example is the mammoth steppe, which evidently was very cold during the winter based on the occurrence of permafrost further south than today (Guthrie, 1990, p. 221), while having an unprecedented diversity of large grazing herbivores. However, this discrepancy does not necessarily affect our MAT estimates because seasonal differences in temperature might cancel each other out. It has been shown that deforestation at high latitudes increases seasonal variation in maximum and minimum temperatures, whereas MAT does not change significantly (Alkama and Cescatti, 2016). This implies that MINT is more likely to be overestimated at high latitudes.

Comparing the number of species between fossil sites merits caution because it can be affected by several factors. Incomplete preservation is of course a fundamental feature of the fossil record, but we are not concerned about that because, according to Andrews (2006) and Polly and Sarwar (2014), even a reduced subset of the original fauna can give a similar ecological signal. Of course, time- 
averaging over thousands of years can bias the results, especially if an ecotone was located close to a depositional site, possibly producing combinations of species that never coexisted together (e.g. Behrensmeyer et al., 2007). The extent to which this could affect our results then depends on the number of species that were exclusive to a single habitat (Andrews, 2006). It is possible that local environmental change over time (e.g. shift in treeline) could lead to overrepresentation of species without acute lophs, while also increasing species count in the process. Although we do not rule out this possibility for some sites, we would expect hypsodonty, and other variables such as NPP, to have stronger correlations with species count if habitat-mixing biased our results in a major way, but they are in fact negligible (Table 4). Regardless, whether or not our results are biased by the fossil record, the positive correlation between species count and temperature is plausible, considering that species richness of mammals, both large and small, tends to be higher in relatively warm and less seasonal climates (e.g. Currie, 1991; Andrews and O'Brien, 2000).

Our study of European Pleistocene sites shows that the new models perform well in the recent past. Performance of the temperature models in the more distant past, such as during times of grassland expansion in the Miocene, exhibiting a lot of structural change in faunal communities (e.g. Kaya et al., 2018), remains to be tested.

\section{CONCLUSION}

The links between geo- and biodiversity, postulated by Humboldt, can now be quantitative. Species are adapted to their environments and interact with their environments by having pertinent functional traits. We can quantify functional traits of communities and develop statistical models linking trait distribution to local climate. We can then apply these models to the fossil record, survey functional traits there, and quantitatively estimate climates of the past. We have shown here how functional traits of species communities carry a strong global environmental signal and we refined dental ecometric models to better reflect biomechanics of chewing, focusing on predicting temperature in particular, which until now has been challenging. Dental ecometric modelling, while not without its limitations, presents a powerful and theoretically backed means to reconstruct palaeoenvironments across spatial and temporal scales.

Alexander von Humboldt clearly sensed the potential embodied in the newly discovered fossil record for investigating and describing what he in Views of Nature (first published in 1807) called the "physiognomy of the aging planet": "If the temperature of the planet underwent significant, possibly periodically recurring changes, if the proportions of land to see and even the height of the atmosphere and its pressure have not always been the same, then the size and shape of organisms may likewise have been subject to manifold changes. Powerful pachyderms, elephantlike mastodons, Owen's Mylodon robustus, and the Colossochelys, a land tortoise six feet in height - these once inhabited the forests that then consisted of gigantic lepidodendrons, cactuslike stigmaria, and numerous varieties of cycads" (Humboldt, 2014, p. 163). And he continued, almost apologetically, recognising his own frustrating limitations: "As I am incapable of completely depicting this physiognomy of the aging planet according to its current traits, I will venture only to bring up those characteristics that best describe each plant group. Despite all the richness and flexibility of our mother tongue, it is still a difficult undertaking to represent in words that which better befits the painter's imitative art of depiction. Also, one should avoid the impression of tediousness that any enumeration of individual forms must invariably elicit" (Ibid.).

Looking back over more than two centuries since these words were written, we may note two things. First, that we are still struggling with words, and that the art of palaeontological reconstruction is flourishing like never before, with mobile, lifelike creatures of the past acting and interacting in their reconstructed habitats such that the naïve observer may have difficulty separating the 
reconstruction from documented reality. And secondly, that we still cannot avoid the tiresome description of detail that making sense of the fossil record demands. We still have to laboriously describe and define the fortification of cusps and the acuteness of lophs and all the technical details of our models and analyses. In many ways the progress has been enormous, unimaginable perhaps to the young Alexander von Humboldt. Yet in other ways he might have felt quite at home with modern methods and reconstructions. They are, after all, more or less what he envisioned.

\section{References}

Alkama, R., \& Cescatti, A. (2016). Biophysical climate impacts of recent changes in global forest cover. Science, 351, 600-604.

Alroy, J. (2003). Taxonomic inflation and body mass distributions in North American fossil mammals. Journal of Mammalogy, 84, 431-443.

Andrews, P. (2006). Taphonomic effects of faunal impoverishment and faunal mixing. Palaeogeography, Palaeoclimatology, Palaeoecology, 241, 572-589.

Andrews, P. \& Hixson, S. (2014). Taxon-free methods of palaeoecology. Annales Zoologici Fennici, 51, 269-284.

Andrews, P., \& O'Brien, E. M. (2000). Climate, vegetation, and predictable gradients in mammal species richness in southern Africa. Journal of the Zoological Society of London, 251, 205-231.

Archer, D., \& Sanson, G. D. (2002). The form and function of the selenodont molar in southern African ruminants in relation to their feeding habits. Journal of Zoology, London, 257, 13-26.

Barr, W. A. (2017). Bovid locomotor functional trait distributions reflect land cover and annual precipitation in sub-Saharan Africa. Evolutionary Ecology Research, 18, 253-269.

Barr, W. A. (2018). Ecomorphology. In Croft, D. A., Su, D. F. \& Simpson, S. W. (eds.), Methods in paleoecology: Reconstructing Cenozoic terrestrial environments and ecological communities (pp. 339-350). Springer, Cham.

Behrensmeyer, A. K., Bobe, R., \& Alemseged, Z. (2007). Approaches to the analysis of faunal change during the East African Pliocene. In Bobe, R., Alemseged, Z., \& Behrensmeyer, A. K. (eds.), Hominin Environments in the East African Pliocene: An Assessment of the Faunal Evidence (pp. 1-24). Springer.

Bellucci, L., Bona, F., Corrado, P., Magri, D., Mazzini, I., Parenti, F., ... Sardella, R. 2014. Evidence of late Gelasian dispersal of African fauna at Coste San Giacomo (Anagni Basin, central Italy): Early Pleistocene environments and the background of early human occupation in Europe. Quaternary Science Reviews, 96, 72-85.

Bertini, A. (2000). Pollen record from Colle Curti and Cesi: Early and Middle Pleistocene mammal sites in the Umbro-Marchean Apennine Mountains (central Italy). Journal of Quaternary Science, $15,825-840$.

Bishop, L. C., Plummer, T. W., Hertel, F., Kovarovic, \& K. (2011) Paleoenvironments of Laetoli, Tanzania as Determined by Antelope Habitat Preferences. In Harrison T. (ed.) Paleontology and Geology of Laetoli: Human Evolution in Context. Volume 1: Geology, Geochronology, Paleoecology and Paleoenvironment (pp. 355-366). Springer, Netherlands.

Blain, H.-A., Bailon, S., \& Agusti, J. (2008). Amphibians and squamate reptiles from the latest early Pleistocene of Cueva Victoria (Murcia, southeastern Spain, SW Mediterranean): Paleobiogeographic and paleoclimatic implications. Geologica Acta, 6, 345-361.

Blain, H.-A., Bailon, S., Agusti, J., Martínez-Navarro, B., \& Toro, I. (2011). Paleoenvironmental and paleoclimatic proxies to the Early Pleistocene hominids of Barranco León $D$ and Fuente Nueva 3 (Granada, Spain) by means of their amphibian and reptile assemblages. Quaternary International, 243, 44-53.

Blain, H.-A., Bailon, S., Cuenca-Bescos, G., Arsuaga, J.L., de Castro, J. M. B., \& Carbonell, E. (2009). Long-term climate record inferred from early-middle Pleistocene amphibian and squamate 
reptile assemblages at the Gran Dolina Cave, Atapuerca, Spain. Journal of Human Evolution, $56,55-65$.

Blonder, B., \& Enquist, B. J. (2014). Inferring climate from angiosperm leaf venation networks. New Phytologist, 204, 116-126.

Böhme, M. (2010). Ectothermic vertebrates, climate and environment of the West Runton Freshwater Bed (early Middle Pleistocene, Cromerian). Quaternary International, 228, 63-71.

Candy, I., Rose, J., and Lee, J. (2006). A seasonally 'dry' interglacial climate in eastern England during the early Middle Pleistocene: palaeopedological and stable isotopic evidence from Pakefield, UK. Boreas, 35, 255-265.

Cattani, L., Cremaschi, M., Ferraris, M. R., Mallegni, F., Masini, F., Scola, V., \& Tozzi, C. (1991). Le gisement du Pléistocéne Moyen de Visogliano (Trieste): Restes humains, industries, environnement. L'Anthropologie, 95, 9-36.

Coope, G. R. (2010). Coleoptera from the Cromerian type site at West Runton, Norfolk, England. Quaternary International, 228, 46-52.

Currie, D. J. (1991). Energy and large-scale patterns of animal- and plant-species richness. The American Naturalist, 137, 27-49.

Damuth, J., \& Janis, C. (2011). On the relationship between hypsodonty and feeding ecology in ungulate mammals, and its utility in palaeoecology. Biological Reviews of the Cambridge Philosophical Society, 86, 733-758. (doi:10.1111/j.1469-185X.2011.00176.x)

Damuth, J., \& Janis, C. M. (2014). A comparison of observed molar wear rates in extant herbivorous mammals. Annales Zoologici Fennici, 51, 188-200.

Dunn, R. E., Strömberg, C. A. E., Madden, R. H., Kohn, M. J., \& Carlini, A. A. (2015). Linked canopy, climate, and faunal change in the Cenozoic of Patagonia. Science, 347, 258-261.

Elith, J., \& Leathwick, J. R. 2009. Species distribution models: Ecological explanation and prediction across space and time. The Annual Review of Ecology, Evolution, and Systematics, 40, 677697.

Erd, K. (1965). Pollenanalytische untersuchungen im Altpleistozän von Voigtstedt in Thüringen. In Kahlke, H. -D. (ed.), Das Pleistozän von Voigtstedt (pp. 259-272). Paläontologische abhandlungen $A$, Paläozoologie 2/3. Akademie-Verlag, Berlin.

Eronen, J. T., Mirzaie Ataabadi, M., Micheels, A., Karme, A., Bernor, R. L., \& Fortelius, M. (2009). Distribution history and climatic controls of the Late Miocene Pikermian chronofauna. Proceedings of the National Academy of Sciences, 106, 11867-11871.

Eronen, J. T., Polly, P. D., Fred, M., Damuth, J., Frank, D. C., Mosbrugger, V., ... Fortelius, M. (2010a). Ecometrics: The traits that bind the past and present together. Integrative Zoology, 5, 88101.

Eronen, J T., Puolamäki, K., Liu, L., Lintulaakso, K., Damuth, J., Janis, C., \& Fortelius, M. (2010b). Precipitation and large herbivorous mammals I: estimates from present-day communities. Evolutionary Ecology Research, 12, 217-233.

Eronen, J. T., Puolamäki, K., Liu, L., Lintulaakso, K., Damuth, J., Janis, C., \& Fortelius, M. (2010c). Precipitation and large herbivorous mammals II: application to fossil data. Evolutionary Ecology Research, 12, 235-248.

Fick, S. E., \& Hijmans, R. J. (2017). Worldclim 2: New 1-km spatial resolution climate surfaces for global land areas. International Journal of Climatology, 37, 4302-4315.

Field, M. H., \& Peglar, S. M. (2010). A palaeobotanical investigation of the sediments from the West Runton Mammoth site. Quaternary International, 228, 38-45.

Fortelius, M., Eronen, J., Jernvall, J., Liu, L., Pushkina, D., Rinne, J., ... Zhou, L. (2002). Fossil mammals resolve regional patterns of Eurasian climate change over 20 million years. Evolutionary Ecology Research, 4, 1005-1016.

Fortelius, M., \& Solounias, N. (2000). Functional characterization of ungulate molars using the abrasion-attrition wear gradient: A new method for reconstructing paleodiets. American Museum Novitates, 3301, 1-36. 
Fortelius, M., Žliobaitè, I., Kaya, F., Bibi, F., Bobe, R., Leakey, L., ... Werdelin, L. (2016). An ecometric analysis of the fossil mammal record of the Turkana basin. Philosophical Transactions of the Royal Society B: Biological Sciences, 371, 1-13. https://doi.org/10.1098/rstb.2015.0232

Galbrun, E., Tang, H., Fortelius, M., \& Žliobaitè, I. (2018). Computational biomes: The ecometrics of large mammal teeth. Palaeontologia Electronica, 21.1.3A, 1-31. https://doi.org/10.26879/786 palaeo-electronica.org/content/2018/2122-global-dentalecometrics

Gibbard, P. L., Head, M. J., \& Walker, M. J. C. (2010). Formal ratification of the Quaternary System/Period and the Pleistocene Series/Epoch with a base at $2.58 \mathrm{Ma}$. Journal of Quaternary Science, 25, 96-102.

Guthrie, D. R. (2001). Origin and causes of the mammoth steppe: a story of cloud cover, woolly mammal tooth pits, buckles, and inside-out Beringia. Quaternary Science Reviews, 20, 549574.

Guthrie, R. D. (1990). Frozen fauna of the Mammoth Steppe: The story of Blue Babe. Chicago and London: The University of Chicago Press.

Head, J.J., Bloch, J.I., Hastings, A.K., Bourque, J.R., Cadena, E.A., Herrera, F.A., ... Jaramillo, C.A. (2009). Giant boid snake from the Palaeocene neotropics reveals hotter past equatorial temperatures. Nature, 457, 715-717.

Hosfield, R. (2016). Walking in a winter wonderland - strategies for Early and Middle Pleistocene survival in midlatitude Europe. Current Anthropology, 57, 653-680.

Humboldt, A. von (2014). Views of nature. Edited by S. T. Jackson \& L. D. Walls, translated by M. W. Person. Chicago: University of Chicago Press, 344 pp. (first edition 1807, Ansichten der Natur.)

IUCN (2014). The IUCN Red List of Threatened Species. Version 2014-1. http://www.iucnredlist.org. Downloaded on April 9, 2014.

Janis, C. M. (1995) Correlations between craniodental morphology and feeding behavior in ungulates: reciprocal illumination between living and fossil taxa. In Thomason, J. (ed.), Functional morphology in vertebrate paleontology (pp. 76-98). Cambridge University Press, Cambridge.

Janis, C. M., \& Fortelius, M. (1988). On the means whereby mammals achieve increased functional durability of their dentitions, with special reference to limiting factors. Biological Reviews of the Cambridge Philosophical Society, 63, 197-230.

Jardine, P. E., Janis, C. M., Sahney, S., \& Benton, M. J. (2012). Grit not grass: Concordant patterns of early origin of hypsodonty in Great Plains ungulates and Glires. Palaeogeography, Palaeoclimatology, Palaeoecology, 365-366, 1-10.

Jernvall, J., Hunter, J. P., \& Fortelius, M. (1996). Molar Tooth Diversity, Disparity, and Ecology in Cenozoic Ungulate Radiations. Science, 274, 1489-1492.

Kahlke, R. -D., García, N., Kostopoulos, D. S., Lacombat, F., Lister, A. M., Mazza, P. P. A. ... Titov, V. V. (2011). Western Palaearctic palaeoenvironmental conditions during the Early and early Middle Pleistocene inferred from large mammal communities, and implications for hominin dispersal in Europe. Quaternary Science Reviews, 30, 1368-1395.

Kaiser, T. M., Müller, D. W. H., Fortelius, M., Schulz, E., Codron, D., \& Clauss, M. (2013). Hypsodonty and tooth facet development in relation to diet and habitat in herbivorous ungulates: implications for understanding tooth wear. Mammal Review, 43, 34-46.

Kappelman, J. (1991). The paleoenvironment of Kenyapithecus at Fort Ternan. Journal of Human Evolution, 20, 95-129.

Kay, R. F., \& Hiiemae, K. M. (1974). Jaw movement and tooth use in recent and fossil primates. American Journal of Physical Anthropology, 40, 227-256.

Kaya, F., Bibi, F., Zliobaite, I., Eronen, J. Tang, H., Fortelius, M. (2018). The rise and fall of the Old World savannah fauna and the origins of the African savannah biome. Nature ecology and evolution 2, pages241-246. 
Kolfschoten, T. van (2014). The Palaeolithic locality Schöningen (Germany): A review of the mammalian record. Quaternary International, 326-327, 469-480.

Kovarovic, K., \& Andrews, P. (2007). Bovid postcranial ecomorphological survey of the Laetoli paleoenvironment. Journal of Human Evolution, 52, 663-680.

Kovarovic, K., \& Andrews, P. (2011). Environmental change within the Laetoli fossiliferous sequence: vegetation catenas and bovid ecomorphology. In Harrison T. (ed.) Paleontology and Geology of Laetoli: Human Evolution in Context. Volume 1: Geology, Geochronology, Paleoecology and Paleoenvironment (pp. 367-380). Springer, Netherlands.

Kovarovic, K., Su, D. F., \& Lintulaakso, K. (2018). Mammal community structure analysis. In Croft, D. A., Su, D. F. \& Simpson, S. W. (eds.), Methods in paleoecology: Reconstructing Cenozoic terrestrial environments and ecological communities (pp. 351-372). Springer, Cham.

Lawing, A. M., Head, J. J., \& Polly, P. D. (2012). The ecology of morphology: The ecometrics of locomotion and macroenvironment in North American snakes. In Louys, J. (ed.), Paleontology in ecology and conservation, Earth system sciences (pp. 117-146). Springer Berlin Heidelberg.

Legendre, S. (1986). Analysis of mammalian communities from the late Eocene and Oligocene of Southern France. Paleovertebrata, 16, 191-212.

Lieth, H. (1975). Modelling the primary productivity of the world. In Lieth, H. \& Whittaker, R. H. (eds.), Primary productivity of the Biosphere (pp. 237-263). Springer, New York.

Liu, L., Puolamäki, K., Eronen, J. T., Mirzaie Ataabadi, M., Hernesniemi, E., \& Fortelius, M. (2012). Dental functional traits of mammals resolve productivity in terrestrial ecosystems past and present. Proceedings of the Royal Society B: Biological Sciences, 279, 2793-2799.

Lucas, P. W. (2004). Dental functional morphology: How teeth work. Cambridge University Press.

Lucas, P. W., Omar, R., Al-Fadhalah, K., Almusallam, S., Henry, A. G., Michael, S., Atkins, A. G. (2013). Mechanisms and causes of wear in tooth enamel: implications for hominin diets. Journal of the Royal Society Interface, 10, 1-9.

Manzi, G., Magri, D., \& Palombo, M. R. (2011). Early-Middle Pleistocene environmental changes and human evolution in the Italian peninsula. Quaternary Science Reviews, 30, 1420-1438.

Meloro, C., \& Kovarovic, K. (2013). Spatial and ecometric analyses of the Plio-Pleistocene large mammal communities of the Italian peninsula. Journal of Biogeography, 40, 1451-1462.

Mendoza, M., Janis, C. M., \& Palmqvist, P. (2002). Characterizing complex craniodental patterns related to feeding behaviour in ungulates: a multivariate approach. Journal of Zoology, 258, 223-246.

Merceron, G., Ramdarshan, A., \& Blondel, C. (2016). Untangling the environmental from the dietary: dust does not matter. Proceedings of the Royal Society B: Biological Sciences, 283, 1-8. http://dx.doi.org/10.1098/rspb.2016.1032

Mudelsee, M., \& Stattegger, K. (1997). Exploring the structure of the mid-Pleistocene revolution with advanced methods of time-series analysis. Geologische Rundschau, 86, 499-511.

Ovaskainen, O., Tikhonov, G., Norberg, A., Blanchet, F. G., Duan, L., Dunson, D., ... Abrego, N. (2017). How to make more out of community data? A conceptual framework and its implementation as models and software. Ecology Letters, 20, 561-576.

Owen-Smith, N., Robbins, C. T., \& Hagerman, A. E. (1993). Browse and browsers: Interactions between woody plants and mammalian herbivores. Trends in Ecology \& Evolution, 8, 158160.

Peppe, D. J., Royer, D. L., Cariglino, B., Oliver, S. Y., Newman, S., Leight, E., ... Correa, E. (2011). Sensitivity of leaf size and shape to climate: global patterns and paleoclimatic applications. New Phytologist, 190, 724-739.

Polly, P. D. (2010). Tiptoeing through the trophics: geographic variation in carnivoran locomotor ecomorphology in relation to environment. In Goswami, A. \& Friscia, A. (eds.), Carnivoran evolution: new views on phylogeny, form, and function (pp. 374-401). Cambridge, UK: Cambridge University Press. 
Polly, P. D., Eronen, J. T., Fred, M., Dietl, G. P., Mosbrugger, V., Scheidegger, C. ... \& Fortelius, M. (2011). History matters: ecometrics and integrative climate change biology. Proceedings of the Royal Society B: Biological Sciences, 278, 1131-1140.

Polly, P. D., Fuentes-Gonzalez, J., Lawing, A.M., Bormet, A.K., \& Dundas, R.G. (2017). Clade sorting has a greater effect than local adaptation on ecometric patterns in Carnivora. Evolutionary Ecology Research, 18, 61-95.

Polly, P. D., \& Head, J. J. (2015). Measuring earth-life transitions: Ecometric analysis of functional traits from late Cenozoic vertebrates. The Paleontological Society Papers, 21, 21-46.

Polly, P. D., \& Sarwar, S. (2014). Extinction, extirpation, and exotics: effects on the correlation between traits and environment at the continental level. Annales Zoologici Fennici, 51, 209226.

Popowics, T. E., \& Fortelius, M. (1997). On the cutting edge: Tooth blade sharpness in herbivorous and faunivorous mammals. Annales Zoologici Fennici, 34, 73-88.

Renault-Miskovsky, J., \& Lebreton, V. (2006). Place de la palynologie archéologique, au regard des longues sequences polliniques de reference. Comptes Rendus Palevol, 5, 73-83.

Robinson, B. W., \& Wilson, D. S. (1998). Optimal foraging, specialization, and a solution to Liem's paradox. The American Naturalist, 151, 223-235.

Royer, D. L., Wilf, P., Janesko, D. A., Kowalski, E. A., \& Dilcher, D. L. (2005). Correlations of climate and plant ecology to leaf size and shape: potential proxies for the fossil record. American Journal of Botany, 92, 1141-1151.

Saarinen, J. (2014). Ecometrics of large herbivorous land mammals in relation to climatic and environmental changes during the Pleistocene. PhD thesis, Department of Geosciences and Geography, University of Helsinki. http://urn.fi/URN:ISBN:978-952-10-9468-2

Sanson, G. (2006). The biomechanics of browsing and grazing. American Journal of Botany, 93, 15311545.

Schnitzler, J., Theis, C., Polly, P. D., \& Eronen, J. T. (2017). Fossils matter - understanding modes and rates of trait evolution in Musteloidea (Carnivora). Evolutionary Ecology Research, 18, 187200.

Soest, P. J. van (1994). Nutritional ecology of the ruminant. Ithaca, NY and London, UK: Comstock Publishing Associates, Cornell University Press.

Solounias, N., \& Dawson-Saunders, B. (1988). Dietary adaptations and paleoecology of the Late Miocene ruminants from Pikermi and Samos in Greece. Palaeogeography, Palaeoclimatology, Palaeoecology, 65, 149-172.

Suc, J. P. (1984). Origin and evolution of the Mediterranean vegetation and climate in Europe. Nature, 307, 429.

Sukselainen, L., Fortelius, M., \& Harrison, T. (2015). Co-occurrence of pliopithecoid and hominoid primates in the fossil record: An ecometric analysis. Journal of Human Evolution, 84, 25-41.

The NOW Community (2018). New and Old Worlds Database of Fossil Mammals (NOW). Licensed under CC BY 4.0. Last retrieved on 1.10.2018 from http://www.helsinki.fi/science/now/.

Traiser, C., Klotz, S., Uhl, D., \& Mosbrugger, V. (2005). Environmental signals from leaves -a physiognomic analysis of European vegetation. New Phytologist, 166, 465-484.

Urban, B., \& Bigga, G. (2015). Environmental reconstruction and biostratigraphy of late Middle Pleistocene lakeshore deposits at Schöningen. Journal of Human Evolution, 89, 57-70.

Vermillion, W. A., Polly, P. D., Head, J. J., Eronen, J. T., \& Lawing, A. M. (2018). Ecometrics: A traitbased approach to paleoclimate and paleoenvironmental reconstruction. In Croft, D. A., Su, D. F. \& Simpson, S. W. (eds.), Methods in paleoecology: Reconstructing Cenozoic terrestrial environments and ecological communities (pp. 373-394). Springer, Cham.

Villa, A., Blain, H.-A., van den Hoek Ostende, L. W., \& Delfino, M. (2018). Fossil amphibians and reptiles from Tegelen (Province of Limburg) and the early Pleistocene palaeoclimate of The Netherlands. Quaternary Science Reviews, 187, 203-219. 
Walker, M., \& Lowe, J. (2007). Quaternary science 2007: a 50-year retrospective. Journal of the Geological Society, 164, 1073-1092.

West, R. G. (1980). The Pre-glacial Pleistocene of the Suffolk and Norfolk Coasts. Cambridge, UK: Cambridge University Press.

White, T.S., Preece, R.C., \& Whittaker, J.E. (2013). Molluscan and ostracod successions from Dierden's Pit, Swanscombe: insights into the fluvial history, sea-level record and human occupation of the Hoxnian Thames. Quaternary Science Reviews, 70, 73-90.

Wing, S. L., Harrington, G. J., Smith, F. A., Bloch, J. I., Boyer, D. M., \& Freeman, K. H. (2005). Transient floral change and rapid global warming at the Paleocene-Eocene boundary. Science, 310, 993-996.

Winkler, D. E., Schulz-Kornas, E., Kaiser, T. M., De Cuyper, A., Clauss, M., \& Tütken, T. (2019). Forage silica and water content control dental surface texture in guinea pigs and provide implications for dietary reconstruction. Proceedings of the National Academy of Sciences, www.pnas.org/cgi/doi/10.1073/pnas.1814081116

Wolfe, J. A. (1995). Paleoclimatic estimates from Tertiary leaf assemblages. Annual Review of Earth and Planetary Sciences, 23, 119-142.

Wulf, A. (2015). The invention of nature: The adventures of Alexander von Humboldt, the lost hero of science. London: John Murray.

Zachos, J., Pagani, M., Sloan, L., Thomas, E., \& Billups, K. (2001). Trends, rhythms, and aberrations in global climate $65 \mathrm{Ma}$ to present. Science, 292, 686-693.

Zheng, D., Prince, S., \& Wright, R. (2003). Terrestrial net primary production estimates for $0.5^{\circ}$ grid cells from field observations-a contribution to global biogeochemical modelling. Global Change Biology, 9, 46-64.

Žliobaitè, l., \& Fortelius, M. (2018). Dental functional morphology predicts the scaling of chewing rate in mammals. Journal of Biomechanics, 63, 32-36.

Žliobaitè, I., Rinne, J., Toth, A., Mechenich, M., Liu, L. P., Behrensmeyer, A. K., \& Fortelius, M. (2016). Herbivore teeth predict climatic limits in Kenyan ecosystems. Proceedings of the National Academy of Sciences, 113, 12751-12756.

Žliobaitè, I., Tang, H., Saarinen, J., Fortelius, M., Rinne, J., Rannikko, J. (2018). Dental ecometrics of tropical Africa: linking vegetation types and communities of large plant-eating mammals. Evolutionary Ecology Research, 19, 127-147.

\section{Biosketches}

Otto Oksanen is a PhD student at the Department of Geosciences and Geography, University of Helsinki. This research was produced in a collaboration between Data Science and Evolution research group lead by Indrė Žliobaitė (https://www.helsinki.fi/en/researchgroups/data-science-andevolution), Evolutionary Palaeontology research group lead by Mikael Fortelius (https://www.helsinki.fi/en/researchgroups/evolutionary-palaeontology-group) and Paleobiology, Evolution and Climate Laboratory lead by Michelle Lawing (https://essm.tamu.edu/people/faculty/lawing-michelle/).

\section{Author contributions}

IŽ, MF and $\mathrm{OO}$ designed the study. OO selected fossil localities, compiled fossil data, did the analysis of estimates and made the case study. IZ did the ecometric modelling and produced the estimates. JS compiled and analyzed comparative palaeoproxies. IŽ and MF updated the dental traits scoring scheme, IŽ scored acute lophs. ML compiled IUCN faunal occurrence data. OO, IŽ and MF wrote the first draft. All authors contributed to the final text. 